\title{
The Refutation of Gorgias: Notes on a Contradiction*
}

\section{REFIK GÜREMEN / Mimar Sinan University /}

In this paper, I would like to argue that in his refutation of Gorgias in the eponymous dialogue, the discovery of truth is not Socrates' primary concern. Actually, I am truly convinced that this is the only piece in the entire Platonic corpus that is overtly personal and pursued for the sake of refuting the interlocutor himself. ${ }^{1}$ Despite Socrates' statement to the contrary ( $\mathrm{Grg} .453 \mathrm{C2}-4)$, I believe that the refutation of the master of rhetoric himself is Socrates' central concern. ${ }^{2}$

The observation that leads me to this conclusion is the following: why would Socrates want to prove, as the conclusion of his refutation of Gorgias, that oratory cannot be used

*A paper on a similar theme was presented at the 2015 meeting of the Mediterranean Section of the International Plato Society at the Aix-Marseille University in Aix-en-Porvence. A French version of this article will appear in La vérité: Platon et les sophistes. Actes du colloque d'Aix-en-Provence (9-11 Octobre 2015), A. Tordesillas et M. Corradi (eds.), Paris (forthcoming).

${ }^{1}$ Yosef Z. Liebersohn's book (2014) is exclusively dedicated to this discussion between Socrates and Gorgias. I think it is an indispensable reference for any bibliography on the subject. For my view on Liebersohn's book, see $n$. 12 below.

2 Pace Dodds (1959: 204), who thinks that passages like Pl. Grg. 453c2-4 reveal that the refutation of the interlocutor is only incidental to the discussion. 
unjustly and that the orator is ipso facto an just person, when just a few passages later he also claims very straightforwardly against Polus that oratory is not an art at all and that it is nothing more than just a 'knack', the business of giving a false appearance of caring for the soul?

To be more precise, I believe that the dialogue is flawed by a major contradiction between the conclusion of the discussion with Gorgias, on the one hand, and the conclusion of the discussion with Polus, on the other hand. What Socrates establishes in the latter is the negation of what he establishes in the former.

The following is my reconstruction of Socrates' refutation of Gorgias:

[1.] Since oratory always makes its speeches about justice, it cannot be used unjustly.

[2.] But Gorgias assumes that although it is about justice, oratory can still be used unjustly. ${ }^{3}$ (This is equivalent to not-[1]).

[3.] [1] and [2] cannot be both true.

We obtain these first three premises from what Socrates says at the very end of the discussion, as the concluding remarks of his refutation of Gorgias: ${ }^{4}$

SOC: And at the beginning of our discussion, Gorgias, it was said that oratory would be concerned with speeches, not those about even and odd, but those about what's just and unjust.

GOR: Yes.

SOC: Well, at the time you said that, I took it that oratory would never be an unjust thing, since it always makes its speeches about justice. But when a little later you were saying that the orator could also use oratory unjustly, I was surprised and thought that your statements weren't consi$\operatorname{stent}^{5}$ (Grg. 46oe2-461a2).

Although these words come at the end of the discussion, they are meant to recapitulate the starting points of Socrates' elenchus. It is not clear on what grounds Socrates makes the inference in the first premise, but it is nonetheless clear that [1], [2], and [3] are the basic assumptions of his argument, which continues as follows:

[4.] Since the orators learn the just as a part of their education, they know it and they speak knowingly about it.

${ }^{3}$ Gorgias assumes (although inconsistently, see n. 20 below) his art to be morally neutral in the sense that it can be used justly or unjustly depending on the moral character and the purposes of the person using it. Gorgias makes this point as a teacher's apology for the possible immoral uses of the art by the students ( $\mathrm{rrg}$. 456c-457c). Murray (2001) discusses the consistency of this claim for moral neutrality.

4 All translations from the Gorgias are by Zeyl (1997).

5 Dodds (1959: 220) thinks that the contradiction detected by Socrates here is between Gorgias's claim that rhetoric is concerned with the just and the unjust and the denial of the teacher's responsibility for any unjust uses of the art by students. Logically speaking, there is no contradiction between these two positions. 
[5.] Since they know the just, they are just persons.

[6.] If it is true that they are just persons, they necessarily act justly.

[7.] If they necessarily act justly, it is impossible that they use oratory unjustly.

[8.] Therefore, oratory cannot be used unjustly.

[9.] Therefore, Gorgias' assumption in [2] is false.

[10.] If [2] is false then [1] must be true.

[4]-[10] restate the bulk of Gorgias' refutation ( Grg. 46ob6-c6). Reading this argument, we understand better what Socrates was after, when he made Gorgias concede (just a few lines before) that if a student does not already know what is just when he comes to him to learn oratory, he will teach him (Grg. 46oa3). When accepting this point, Gorgias is actually answering the following question:

SOC: [If the prospective student doesn't know what's just and unjust, etc.] will you, the oratory teacher, not teach him any of these things when he comes to you - because this is not your job [...]. Or won't you be able to teach him oratory at all, unless he knows the truth about these things to begin with? (Grg. 459e3-8).

Gorgias' answer to this question is, in fact, just an elliptical way of saying: "No, Socrates, I won't be able to teach him oratory at all if the student doesn't know what's just beforehand. If he doesn't know what's just, right, I'll teach him”. It is only after Gorgias concedes this point that Socrates brings in his intellectualist thesis that the knowledge of the just makes one a just person ( $\mathrm{Grg} .46 \mathrm{ob} 7) .{ }^{6}$ Obtaining these concessions from Gorgias, Socrates guarantees his consent for the following two statements:

[A] Knowledge of what is just is a necessary condition for being an orator (or equivalently: if someone is an orator, then he knows what is just).

and if $[\mathrm{A}]$, then

[B] Being a just person is a necessary condition for being an orator (or equivalently: if someone is an orator, then he is a just person).?

6 Analyzing Socrates' question here and Gorgias' answer to it, Alessandra Fussi (2002: 134-135) claims that Gorgias' answer can be understood in three ways: He might be taken to mean that a) the knowledge of the just and the unjust should only be counted as a part of the curriculum of the education in rhetoric or that b) the knowledge of such notions is also an ingredient of the art itself, or that c) such knowledge is only a requirement for learning the art without which, however, no teaching of rhetoric would be possible. Fussi thinks that in his answer, Gorgias goes only so far as to admit a). Although I do not deny that these distinction can be read into Gorgias' answer, I still cannot see what difference they would make to Socrates. In all three cases, the knowledge of the just and the unjust is posited to be a necessary condition for being an orator, and that is all Socrates needs for the intellectualist premise (premise no. 5 above) of his refutation of Gorgias.

7 This statement can also be inferred from [4] and [5]. This seems to be an essential assumption in Socrates' argument. 
Now, I want to proceed by explaining that what Socrates establishes in his discussion with Polus is inconsistent and in contradiction with statements [1], [A], and [B]. But prior to that, let us note that what Socrates establishes in his refutation of Gorgias has a modal force: it implies that there could not be an unjust orator who could use oratory for unjust purposes, given that being an orator requires having learned, that is, having acquired the knowledge of what is just. Socrates' argument with Gorgias, therefore, is a modal one, not a normative one. In other words, the oratory that Socrates is discussing here is not his ideal of oratory. It is, I believe, obvious enough that Socrates is talking about the sort of oratory that Gorgias practices and teaches (whatever that is).

Polus gets involved in the discussion with the motivation of arguing against the three aforementioned statements ([1], [A], and [B]) that Socrates established as the conclusions of his refutation of Gorgias. Polus wants to argue that oratory can be used unjustly and that this, in fact, is its most beneficial use. Socrates attacks. But this time what he attacks is not the idea that oratory can be used unjustly but that its unjust use is the most beneficial thing for a person. It is to prove that unjust uses of oratory can in no way be beneficial for a person who has done the injustice that Socrates offers two of his most famous theses, namely: a) doing what is unjust is more shameful and worse than suffering something unjust, and b) not paying what is due when one has done injustice is the worst of all things. He makes this detour to arrive at the conclusion that "for the person who has no intention of behaving unjustly, oratory does not seem to have much use - if in fact it has any use at all" (Grg. 481b1-4).

It is now more or less obvious how the conclusions of the refutations of Gorgias and Polus contradict each other. However, before looking at these contradictions in detail, it is advisable to underline an inconsistency between the two refutations. At the very outset of his confrontation with Polus, Socrates asserts, squarely and without giving any reasons, that oratory is a shameful, bad thing ( $\mathrm{Grg} .463 \mathrm{~d} 4-5)$. We would not expect an activity that cannot be used unjustly (as proved against Gorgias) to be a shameful thing; and we would not expect the orators, who are necessarily just persons, to do bad and shameful things.

As for the contradictions, we need to start by noting that in his long opening speech against Polus, Socrates states that oratory is an image and counterpart of a part of politics, namely justice ( $\mathrm{Grg} .465 \mathrm{c} 3$ ). It follows that the oratory at stake here is also a speech about justice, just as agreed by Gorgias and Socrates in the previous discussion (and stated as the antecedent of statement [1] above). It is true that according to Plato oratory has only the false appearance of being an art. However, this does not entail that it is only apparently about justice. Oratory does not pretend to be about justice. It is about justice. What Socrates deplores about oratory is its pretention to provide care for the soul: oratory gives the false appearance of caring about the soul, but in fact it does not care about it. To put it more synthetically: Socrates deplores the fact that oratory approaches justice in a way that does not care for the soul. Thus, we retain this point: Socrates takes oratory to be a speech about justice.

Now, if we follow the flow of Socrates' speech against Polus, we can observe the following contradictions with statements [1], [A], and [B]. 
ᄂ Socrates states what he takes to be the real crafts that truly provide a state of fitness for the body and the soul. There are four of them: gymnastics and medicine for the body, legislation and justice for the soul. Flattery, of which oratory is a part, takes notice of this division and divides itself into four and it masks itself with each of these parts. But, Socrates says, flattery does not make this division by virtue of some scientific knowledge; it just happens to imitate the real crafts well: "Flattery takes notice of [the fourfold division of the real crafts], I won't

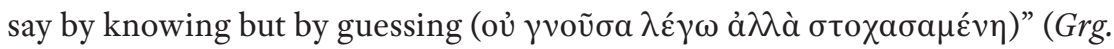
$464 c 6)$. After this, Socrates proceeds to explain why he does not consider orato-

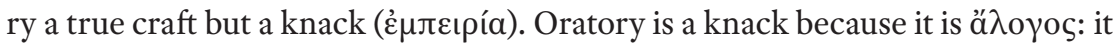
cannot provide any rational explanation for what it does; and Socrates refuses to call such thing a craft (Grg. 465a2-6). ${ }^{8}$ Therefore, Socrates believes that oratory is a speech about justice and yet it does not involve any knowledge of what is just, which entails that:

[not-A] there are orators who do not know what is just.

\Socrates's refutation of Polus arrives at the conclusion that "for the person who has no intention of behaving unjustly it does not seem to have much use" ( $\mathrm{Grg}$. 481b1-4). This is more or less a restatement of what he said a few lines back at 48ob7-9: "If oratory is used to defend injustice, Polus, [...] it is of no use to us at all". I take it that with the word "us" here, Socrates means those whose intentions are just. It is not clear why Socrates thinks that oratory is not of much use for just purposes, since a few lines later he suggests that it can be useful for those who want to purify themselves and others from the injustices they commit. Such a use does not seem useful enough to Socrates. I shall not dwell on this point. I just want to underline that the conclusions which Socrates arrives at about oratory here entail that:

[not-1] oratory is a speech about justice and yet it can still be used for unjust purposes;

and [not-B] certain orators can be unjust.

I suppose this is enough to establish that in the Gorgias Socrates is represented as holding contradictory beliefs about the relation between knowledge, justice, and oratory. This, however, is only one part of my claim in the present paper, as I also would like

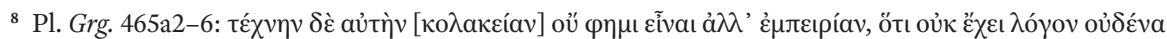

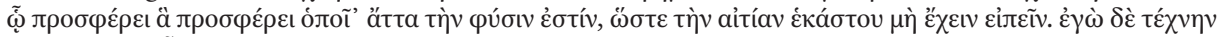

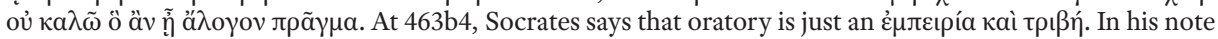

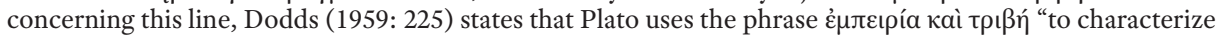
procedures which he thinks unscientific". His other references are: Pl. Grg. Phdr. 270b; Phlb. 55e and Lg. 938a. 
to argue that Socrates is being personal in his discussion with Gorgias, for he aims at Gorgias himself rather than the truth. ${ }^{9}$ Before I give my reasons for the latter claim, I want to consider a possible objection to my interpretation so far.

One might object that the refutation of Gorgias aims only at revealing the inconsistency of his beliefs and Socrates does not necessarily endorse the conclusion. I believe that this view is incorrect. The way I have reconstructed Socrates' argument above makes it a standard elenchus. ${ }^{10}$ Following Vlastos' analyses of Socrates' use of the elenctic argument form, we can conclude that Socrates must be taking the negation of premise [2] to be proved. ${ }^{11}$ In support of this view, I shall show that two very crucial premises in the refutation are actually Socrates' own beliefs and the way he introduces these premises is far from being adequately justified.

The first one is premise [1] of the refutation as reconstructed above. Let us recall that this premise is blurted out by Socrates at the very end of the discussion ( $\mathrm{Frg}$. 460e2-461a2) when he confesses that when he first heard Gorgias saying that oratory is about what is just and unjust he took it that oratory could never be an unjust thing, since it would always make its speeches about justice. But Gorgias disappoints him. I quote again his complaint: "But when a little later you were saying that the orator could also use oratory unjustly, I was surprised and thought that your statements weren't consistent." Gorgias disappoints Socrates because Socrates expected him to make the "most obvious" inference that if a speech is about justice then it cannot be used unjustly. Gorgias was not aware of this truth. ${ }^{12}$ However, this implies that the "most obvious" inference, which Socrates appeals to as the first premise of his refutation, is his own assumption: he never tries to justify it, nor does he ask for Gorgias' consent to it. He just provides it for himself. ${ }^{13}$

9 The idea that Socrates is arguing ad hominem against Gorgias has been put forward by Khan (1983) and Fussi (2001). Both seem to think that Socrates is actually endorsing as his own views what he says against Gorgias. My claim in this paper is also that Socrates is endorsing these views as his own. But I mean it in a different sense than Khan and Fussi. In my opinion, Socrates advocates these ideas as his own but he does that just for the sake of the argument.

${ }^{10}$ More precisely, it is rather a direct elenchus where the refutand (i.e. premise [2]) does not serve as a premise from which its negation is deduced. For the relevance of the distinction between direct and indirect arguments for the Socratic elenchus, see Robinson (1953: 21-34).

11 On this point see Vlastos (1994: esp. 17-20), who claims that in his elenctic arguments Socrates goes beyond revealing to his interlocutors the inconsistency of their set of beliefs and takes the negation of the refutand to be proved. In other words, Socrates' elenctic arguments entail the truth of his thesis in a discussion.

12 I believe that Liebersohn (2014) is reading too much into Plato's use of the difference between the terms rhêtorikos and rhêtôr in the Socrates-Gorgias conversation. Nevertheless, if I were to restate my point in his terms, I would say that in his conversation with Gorgias Socrates is taking advantage of Gorgias' vacillation between these terms in order to lead him into whatever contradiction. Liebersohn, on the other hand, claims that Socrates makes use of this vacillation in order to overcome Gorgias' unwillingness to associate himself with the "bad rhêtôr-es", who misuse the art of rhetoric for unjust purposes. Pace Liebersohn, I really cannot see why Socrates would conclude his discussion with Gorgias by denying any such misuse, if his intention is actually to associate him with such misuses.

${ }^{13}$ One might object that if Socrates does not take Gorgias' consent to that premise, then the way I reconstruct his argument cannot be a standard elenchus. But note that this premise is the negation of the premise [2]. And the assertion of its truth is the conclusion of the elenchus. What Socrates says as the concluding remarks 
The other premise through which Socrates introduces one of his own assumptions without any adequate justification is premise [5]. The speed with which Gorgias gives his consent to this otherwise very complicated idea is intriguing. To put it very briefly, the "knowledge" which is at stake in this premise can be either a) the definitional knowledge of what is just or b) the knowledge how to do just things. The crafts analogy (Grg. 46obd) suggests the latter, ${ }^{14}$ whereas what Socrates says to make Gorgias concede that he would teach what is just to an ignorant student suggests that the knowledge in question is knowledge of the truth about what is just. ${ }^{15}$ I claim that Plato is intentionally being equivocal here, to make Gorgias' rapid consent seem more plausible than it would otherwise be. After all, a man who knows how to act justly is more likely to be a just person than a professor who lectures on justice at a university. This part of the dialogue is traditionally considered to be the locus classicus of the so-called "moral paradox". I believe that without the crafts analogy, Socrates would not be able to obtain Gorgias' consent so rapidly for the doctrine that virtue is knowledge and that knowledge necessarily results in virtuous action. Without the crafts analogy, Gorgias would not consent so rapidly because, far from being obvious, proving the elements of this doctrine ${ }^{16}$ takes first a discussion with Polus and then another one with Callicles! This would evidently take more than a short session on crafts! $!^{17}$ The crafts analogy gives the impression that Gorgias is consenting so easily because he is picking out and giving consent to an idea from his own set of beliefs. But this is misleading. Gorgias is answering a know-how question, whereas the analogy is designed by Socrates to obtain a consensual answer to a question concerning the knowledge of truth about what is just. This is to say that what Gorgias takes himself to be consenting to is not the same as what Socrates takes himself to be obtaining. ${ }^{18}$ Whether

of his discussion with Gorgias shows that this premise was what he was trying to prove all along. Its truth was assumed and the entire elenchus was tailored to prove it. This supports Vlastos' argument.

${ }^{14}$ The crafts analogy states that a man who has learned carpentry is a carpenter and, in the same way, a man who has learned what is just would be a just man.

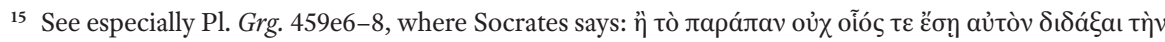

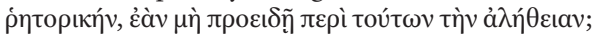

${ }^{16}$ I am referring here to Santas' classical article (1964).

17 Doyle (2012) thinks that "Socratic intellectualism" is abandoned in the Gorgias. According to the traditional understanding of "Socratic intellectualism", Socrates identifies virtue with propositional knowledge, which is not irreducibly practical. Doyle claims that in the Gorgias Socrates expresses a moderate intellectualism in which the relation between knowledge and virtue can always be recast in a way to include emotional and practi$\mathrm{cal}$ aspects. He suggests, for instance, that the intellectualism appealed to in the refutation of Gorgias (Grg. 460b) can be analyzed into knowledge-how, as suggested by the crafts analogy. I do not agree with Doyle. For my objection, see the next note. A claim that I find more plausible about Socrates' appeal to his interlocutors' emotions and practical concerns can be found in Domaradzki (2008). Without claiming that Socrates' intellectualism in the Gorgias can be recast into a know-how, Domaradzki argues that in an ancillary manner to his rational dialectic, Socrates has recourse to a "noble rhetoric", which serves him to stimulate his interlocutors' emotions in order to talk them into his own moral theses.

18 Doyle (2012) suggests that the intellectualist position held by Socrates can be recast into a know-how or a form knowledge which is not purged from all emotional and practical aspects. I believe that Doyle's claim seems plausible mostly because of the equivocality of the way Socrates uses the distinction between propositional knowledge and knowledge-how. 
the latter belongs to Gorgias' set of beliefs is not established by the crafts analogy, simply because Socrates is being equivocal. Thus, I conclude that by using the analogy with the crafts and being equivocal between two senses of knowledge, Plato unjustifiably obtains Gorgias' consent to his own doctrine. ${ }^{19}$ Plato is hasty to give a Socratic twist to the argument that will lead it to a Socratic conclusion. ${ }^{20}$

The speed of the crafts analogy brings me to my claim that Socrates is being personal with Gorgias. I believe that Plato is looking for a rapid, easy refutation of Gorgias. His motivation for doing this could be his desire to show his aptitude for easily refuting the master of rhetoric and preparing the reader for the intellectual aptness of the arguments he is going to develop against Polus and Callicles. From Socrates' point of view, his easy refutation of Gorgias would be a show-case that would intimidate his other interlocutors. My reasons for this claim are the following.

Firstly, in the crafts analogy, when Socrates asserts that a just person, who knows what is just, would never act unjustly, it is not clear why Plato does not let Gorgias object to Socrates with the thesis Socrates himself defends in the Hippias Minor, namely that the more powerful and wiser one gets about justice, the more one is apt to voluntary injustice. If Plato gave Gorgias the same force as the Socrates of the Hippias Minor, things could have turned out differently.

Secondly, at $454 \mathrm{~d}-\mathrm{e}$, Gorgias describes the greatest good that oratory produces for the humankind as follows:

GOR: [...] It is the source of freedom for the humankind itself and at the same time it is for each person the source of rule over others in one's own city [...]. I am referring to the ability to persuade by speeches judges in a law court, councillors in a council meeting, and assemblymen in an assembly or in any other political gathering that might take place. In point of fact, with this ability you'll have the doctor for your slave, and the physical trainer, too. As for this financial expert of yours, he'll turn out to be making more money for somebody else of himself; for you, in fact, if you've got the ability and to speak and to persuade the crowds.

Clearly, Gorgias' expectations are not as ambitious as are those of Polus when it comes to what can be obtained through oratory. Nevertheless, even this small amount of ambition could have been enough to start exactly the same argument with Gorgias as

19 Doyle (2012: 1, n. 1) also thinks that Socrates endorses as his own view the intellectualist thesis that he appeals to against Gorgias (note, however, that according to Doyle this is a "moderate intellectualism" - see n. 17 above). The same is true for Alessandra Fussi's interpretation of Socrates' argument. She thinks that against Gorgias' claim for an omnipotence of oratory, Socrates claims an omnipotence for reason and knowledge and he is represented by Plato as endorsing an intellectualist position. However, Fussi also claims that Plato must not be taken to identify himself with Socrates here because various other aspects of the dialogue (especially those regarding the psychic disorder discussed with Callicles) are in discrepancy with the intellectualist position held by Socrates. Doyle (2012) also makes a similar point. This is a different issue than the one I discuss in the present paper. The issue for Fussi and Doyle is to know whether Plato recognizes the phenomenon of akrasia.

${ }^{20}$ Although for different reasons, Domaradzki (2008) also claims that in the Gorgias, Socrates refutes a Gorgias that he himself concocts. 
with Polus. Gorgias' mediocre ambitions seem to be unjust enough to invite questions about whether what he says is really the highest good for humankind. Plato does not go this way with Gorgias. He prefers a much more rapid, less substantial and equivocal argument to refute the master orator.

Furthermore, what Gorgias praises about oratory in the above passage contradicts his later claim that teachers of oratory preach just uses of oratory and should not be blamed for any unjust uses by their students. Plato just does not seem to see this obvious and easy contradiction. But this could have been a perfect occasion to highlight an internal contradiction in Gorgias' set of beliefs and an opportunity to entangle him in an aporia. This way, the refutation could have been even more rapid and much more convincing. But Plato does not seem to see the contradiction. Instead, he goes on with an equivocal argument through the tortuous crafts analogy, which gives the impression that rather than pointing to a real inconsistency in Gorgias' set of beliefs, Socrates is more interested in ensnaring him. ${ }^{21}$ This last point also supports my claim that Socrates' attention is mainly directed at proving the ideas he himself endorses: Gorgias' own contradictions are of lesser interest, unless they touch a belief that Socrates endorses. ${ }^{22}$

Finally, one might insist that we should not take the conclusions Socrates establishes against Gorgias to be his own beliefs. For the true Socratic opinions, we should rather look at the later discussions with Polus and Callicles, because this is where the real substance of the dialogue lies. According to this objection, Socrates' own beliefs about oratory can be found in his long opening speech against Polus at $464 \mathrm{~b}-466 \mathrm{a}$. Here, Socrates asserts that orators do not know what the just and justice are and, lacking such knowledge, they are not able to speak scientifically about it.

It is certainly true that this opening speech against Polus reflects Socrates' own convictions about the orators. But it is also true that this is exactly what Gorgias would have said if Socrates had let him speak for himself. Gorgias had already accepted that orators speak of, say, medicine, without being knowledgeable about it ( $\mathrm{rrg}$. 458a-459c), and he was ready to say exactly the same thing about justice, too. He was prepared to say that just as in the case of other crafts, orators speak about justice without knowing it: this was already in the logic of his position. ${ }^{23}$ But Socrates does not let him say that! Before

${ }^{21}$ Murray (2001) also discusses the inconsistency between Gorgias' portrayal of rhetoric at 454d-e and his disclaimer of responsibility, as a teacher, for any possible unjust uses of this art by the students. Murray claims that this inconsistency allows Plato to caution the readers against Gorgias' claim for a moral neutrality for his art and to reveal the actual immorality of it. I cannot agree with this interpretation because if this was really Plato's intention in introducing this obvious inconsistency in Gorgias' position, we would expect him to exploit it explicitly and more insistently. He does not do so. The intrinsic immorality of his art is not the corner where Socrates ensnares Gorgias. Socrates does actually the opposite of what Murray says: he reproaches Gorgias for not being aware of the fact that his art cannot be immoral.

22 The last two points corroborate the first one. The inconsistency between the kind of omnipotence that Gorgias claims for his art at 454d-e and his claim for moral neutrality regarding the uses of it implies that Gorgias is actually inclined to hold a position similar to the one held by Socrates in the Hippias Minor.

${ }^{23}$ This is actually the most crucial point about the omnipotence that Gorgias so arduously attributes to his art. According to him, the art of rhetoric is so omnipotent that it can be persuasive on any given subject without 
Gorgias continues, Socrates intervenes and gives him a second chance to reconsider his position regarding justice, and asks him if an orator would behave in the same way with respect to justice as he does with respect to other crafts ( $\mathrm{rrg}$. 459d-e). Gorgias wavers, and gets trapped in Socrates' refutation. If Socrates had not interfered this way, Gorgias would have been ready, and even willing (see Pl. Grg. 459c), to say, just like Socrates does against Polus, that orators do not know what the just and justice are and, lacking such knowledge, they cannot speak scientifically about it.

All things considered, I conclude that rather than developing a substantial argument against Gorgias, in the discussion Socrates just uses whatever way he can best to refute him. When refuting Gorgias in this way, he refutes what he goes on to defend against Polus in the upcoming discussion.

the orator being knowledgeable about it at all. See Fussi (2002: 124-133) on the place of Gorgias' claim for his art's omnipotence in his discussion with Socrates. 


\section{BIBLIOGRAPHY}

DodDs, E. R. (ed.), 1959, Plato, Gorgias. Revised Text with Introduction and Commentary, Oxford.

DomaradzKi, M., 2008, "Plato's Ambivalence about Rhetoric in the Gorgias", Eos 95, pp. 19-31.

DoyLE, J., 2012, “Intellectualism and the Elenchus” (unpublished paper), Pennsylvania Circle of Ancient Philosophy, March 2014; International Plato Society meeting, Ann Arbor, September.

Fussi, A., 2002, “Socrates' Refutation of Gorgias”, Proceedings of the Boston Area Colloquinum in Ancient Philosophy 27, pp. 123-145.

KHAN, C., 1983, “Drama and Dialectic in Plato's Gorgias”, Oxford Studies in Ancient Philosophy 1, pp. 75-121.

LIEBERsohn, Y., 2014, Who is afraid of the rhêtôr?, Piscataway.

MurRay, S. J., 2001, “Plato on Power, Moral Responsibility and the Alleged Neutrality of Gorgias' Art of Rhetoric (Gorgias 456c-457b)", Philosophy and Rhetoric 34, pp. 355-363.

RobInson, R., 1953, Plato's Earlier Dialectic, Oxford.

Santas, G., 1964, “Socratic Paradoxes”, Philosophical Review 73, pp. 147-164.

Vlastos, G., 1994, Socratic Studies, Cambridge.

ZEYL D. J. (transl.), 1997, “Gorgias”, in Plato, Complete Works, J. M. Cooper (ed.), Indianapolis-Cambridge.

REFIK G ÜR EMEN

/ Mimar Sinan University, Turkey / refikg2001@yahoo.com

\section{The Refutation of Gorgias: Notes on a Contradiction}

This paper claims that Socrates' refutation of Gorgias in the eponymous dialogue is designed not to find out the truth about the nature of the art of rhetoric itself but to refute the master of rhetoric himself. I try to justify this claim by displaying some major contradictions between the conclusions reached at with Gorgias and those reached at with Polus. When these contradictions are taken into account, the discussion with Polus is to be seen as reflecting the genuine Socratic position about rhetoric, whereas the discussion with Gorgias seems only to be devised as a dexterity in refutation.

Gorgias, Polus, Socrates, rhetoric

K E Y WORD S 